\title{
A Review of Climate Economic Models in Malaysia
}

\author{
Thirupathi Rao ${ }^{1}$ and Siti Indati Mustapa ${ }^{2, *(1)}$ \\ 1 College of Graduate Studies, Universiti Tenaga Nasional, Jalan IKRAM-UNITEN, Kajang 43000, Selangor, \\ Malaysia; rupath77@gmail.com \\ 2 Institute of Energy Policy \& Research (IEPRe), Universiti Tenaga Nasional, Jalan IKRAM-UNITEN, \\ Kajang 43000, Selangor, Malaysia \\ * Correspondence: indati@uniten.edu.my
}

check for

updates

Citation: Rao, T.; Mustapa, S.I. A Review of Climate Economic Models in Malaysia. Sustainability 2021, 13, 325. https://doi.org/10.3390/ su13010325

Received: 25 October 2020 Accepted: 26 November 2020 Published: 31 December 2020

Publisher's Note: MDPI stays neutral with regard to jurisdictional clai$\mathrm{ms}$ in published maps and institutional affiliations.

Copyright: $(\odot 2020$ by the authors. Licensee MDPI, Basel, Switzerland. This article is an open access article distributed under the terms and conditions of the Creative Commons Attribution (CC BY) license (https:// creativecommons.org/licenses/by/ $4.0 /)$.

\begin{abstract}
This paper presents a review of literature on the development of climate economy models in Malaysia from 1988 to 2020. The type of climate economic models used in Malaysia and their attributes were analyzed. The key attributes reviewed include functions, capability, the various approaches, types of Greenhouse gas (GHG) emissions, and various sectors included in the modelling. The review analysis revealed that climate economic modelling in Malaysia can be categorized into two groups namely Input-Output (I-O) table and Social Accounting Matrix (SAM) models as well as the Integrated Assessment Models (IAM). Both groups of climate economic models complement each other in functional capability to do top-down or bottom-up as well as short-term and long-term analysis. The key contribution of this review is in discovering three key gap clusters that exist in climate economic modelling in Malaysia. These gaps include the coverage on types of GHGs, disclosing the GHG sector's coverage in the modelling, and the discovering of the exclusion of climate damage functions as well as the unavailability of customized functions to suit Malaysia's climate and geography. These three key gaps need to be urgently addressed for effective policy interventions in Malaysia and to meet the global goals of the Paris Agreement.
\end{abstract}

Keywords: carbon price; climate economic modelling; Malaysia; climate change; greenhouse gas emissions

\section{Introduction}

The concept of externalities in the production of goods and services by Arthur Pigou became part of economics with the publication of "The Economics of welfare" [1]. GHG emissions became a negative global externality from production activities causing global warming and climate change [2]. Society needs to adapt to the catastrophic consequences if governments across the globe delay in taking any unprecedented policy corrections [3-5].

A price on GHG emissions determined from climate economic modelling is called Social Cost of Carbon (SCC) or carbon price. SCC is defined as the net present value of climate damages from one more tonne of carbon dioxide $\left(\mathrm{CO}_{2}\right)$ or equivalent, conditional on a global emissions trajectory over time [6,7]. Among others, setting a price on greenhouse gas emissions is one of the effective policy instruments to address the negative externalities of anthropogenic greenhouse gas emissions $[5,8,9]$. Carbon pricing is implemented in almost 61 jurisdictions around the world covering 22\% of global GHG emissions based on a report by the World Bank in 2020 [9]. According to this report, the range of carbon prices starts from $1 \mathrm{USD} / \mathrm{tCO}_{2} \mathrm{e}$ to $119 \mathrm{USD} / \mathrm{tCO}_{2} \mathrm{e}$. However, the percentage coverage of global GHG emissions has almost doubled from 13\% in 2016 with only 40 jurisdictions [10]. The year 2016 was selected to compare the state of the global carbon pricing in the postParis Agreement in 2015. This is evidence by the adoption of carbon pricing which is expected to build its pace following this growing trend [9].

With so much momentum globally, discussion on carbon price just began to take its stage in Malaysia's national plans. The 11th Malaysian Economic Development Plan mentioned the possibilities of green tax or carbon tax to fund green financing mechanisms [11]. 
However, there was no carbon price mentioned in Malaysia's Nationally Determined Contribution [12]. This could be due to a lack of awareness or information on the climate impact on the local economy [13]. Climate Change impact on the local economy can be proven with climate economic modelling [14].

A simple benchmarking was done on carbon price levels in developing countries as shown in Figure 1 [9]. Malaysia can also simply set carbon price below the highest value amongst the five developing countries which is $7 \mathrm{USD} / \mathrm{tCO}_{2} \mathrm{e}$. However, it is not so simple as it sounds. Carbon price is supposed to be close to $40 \mathrm{USD} / \mathrm{tCO}_{2} \mathrm{e}$ presently and gradually grows up to $80 \mathrm{USD} / \mathrm{tCO}_{2} \mathrm{e}$ to meet the Paris Agreement goals [15] or a price close to $100 \mathrm{USD} / \mathrm{tCO}_{2}$ e to prevent the catastrophic impact of climate change [8]. In reality, the carbon prices in all of the developing countries in Figure 1 are far lower than the expected carbon price levels to meet the Paris goals as quoted above.

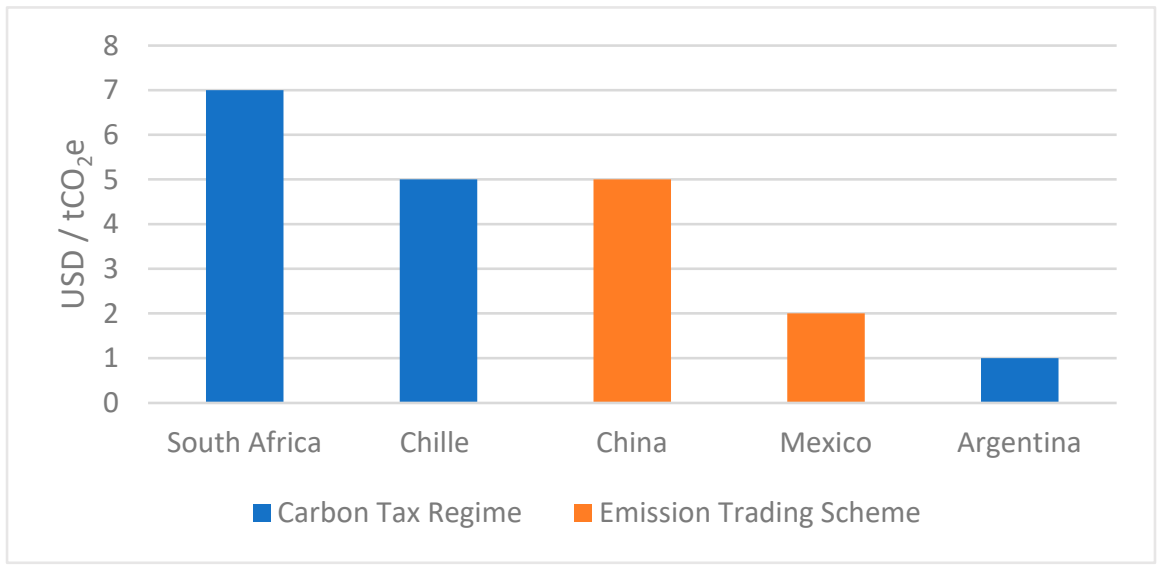

Figure 1. Carbon Price Levels in Developing Countries.

Furthermore, the economic impacts of introducing carbon price for the short and long term in Malaysia need to be carefully studied with a fair reflection on climate change externalities. This requires climate economic modelling unique to Malaysian economy and climate. Climate economic models which included the economy, climate science, technology development, and social cost is the best tool for such analysis to provide a clearer cost-benefit analysis. Such work in developing countries is limited [16]. This paper adds value in the field of climate economics by identifying limitation and gaps of current climate economic modelling in Malaysia and recommends the improvement which will have positive policy implications in Malaysia.

\section{Methodology}

A systemic review approach was adopted [17] for this review with a four (4) step process of pre-planning, review planning, conducting the review as well as results and discussions. The pre-planning step is an added step in this review to enable a better design of planning, analysis, and discussion processes.

\subsection{Pre-Planning}

Understanding the literature of climate economics is important before proper planning for the review process. The scientific literature from the Intergovernmental Panel on Climate Change (IPCC) was reviewed to identify global climate economic models used and the key attributes or dimensions to classify these models. The modelling frameworks of various climate economic models were studied to identify the differences to group them into different dimensions. The understanding of climate economic modelling dimensions was later useful for developing a suitable framework to analyze the climate economic models in Malaysia. 
A literature review on historical trends and developments in managing the issue of climate change in Malaysia was conducted to gain a good understanding of Malaysia's position in global climate negotiations, local policies, and climate economic-related works. This background literature review is important to identify the period where the need for climate economics emerge in Malaysia and how it has progressed up to date.

\subsection{Review Planning}

The first step in planning for a review is to clearly articulate the objective of the review with a set of questions [17]. Three (3) specific questions were established to meet the objective of the review as follows;

1. When did climate economics modelling began in Malaysia and their trends?

2. What type of climate economic models are used in Malaysia?

3. What are the key gaps in climate economic models in Malaysia?

To answer these questions, a search was conducted using the Scopus database. Conference proceedings, books, case studies, reports, editorials, and review articles were excluded from the search process.

Key phrases used for the search include "climate change in Malaysia", "carbon price in Malaysia". Since these phrases will result in a huge number of articles, a set of criteria was established to refine the search. The filtering criteria are given as follows:

4. Papers must be relevant to climate economics discussions in Malaysia or ASEAN region where Malaysia is mentioned.

5. Papers must have carbon price discussions with applied computable general equilibrium concepts.

\subsection{Conducting the Review}

The papers that met the set criteria were organized in excel and any duplication is removed by double-checking on the title of the paper, author, and year of publication. A document analysis protocol was innovated from previous literature $[18,19]$ and the information was populated in an excel table. The document analysis protocol consists of the following parameters;

6. Year of publication or conference

7. Authors

8. Journal or Conference name

9. Title of Paper

10. Type of climate economics modelling and its dimensions

11. Key summary points of the paper on climate economics modelling and carbon price

\subsection{Results and Discussion}

The results of the review in terms of historical trends of papers, types of modeling, and respective dimensions are synthesized into diagrams and tables. Limitations and gaps in current modelling work in Malaysia were identified by examining which industry or economic sector the paper was addressing, which parameters are exogenous and endogenous, the scope of data input, etc. Finally, policy implications and recommendations for future improvements were discussed based on the results of limitation and gap analysis.

The above four steps systematic approach is simplified and shown in Figure 2. 


\section{Step 1 : Pre-Planning}

1. Literature review to understand global climate economic modelling .

2. Identify the key dimensions to classify the models and propose a framework for review in Malaysia.

3. Literature review on historical trend and developments in managing the issue of climate change to identify the period of advent of climate economics in Malaysia.

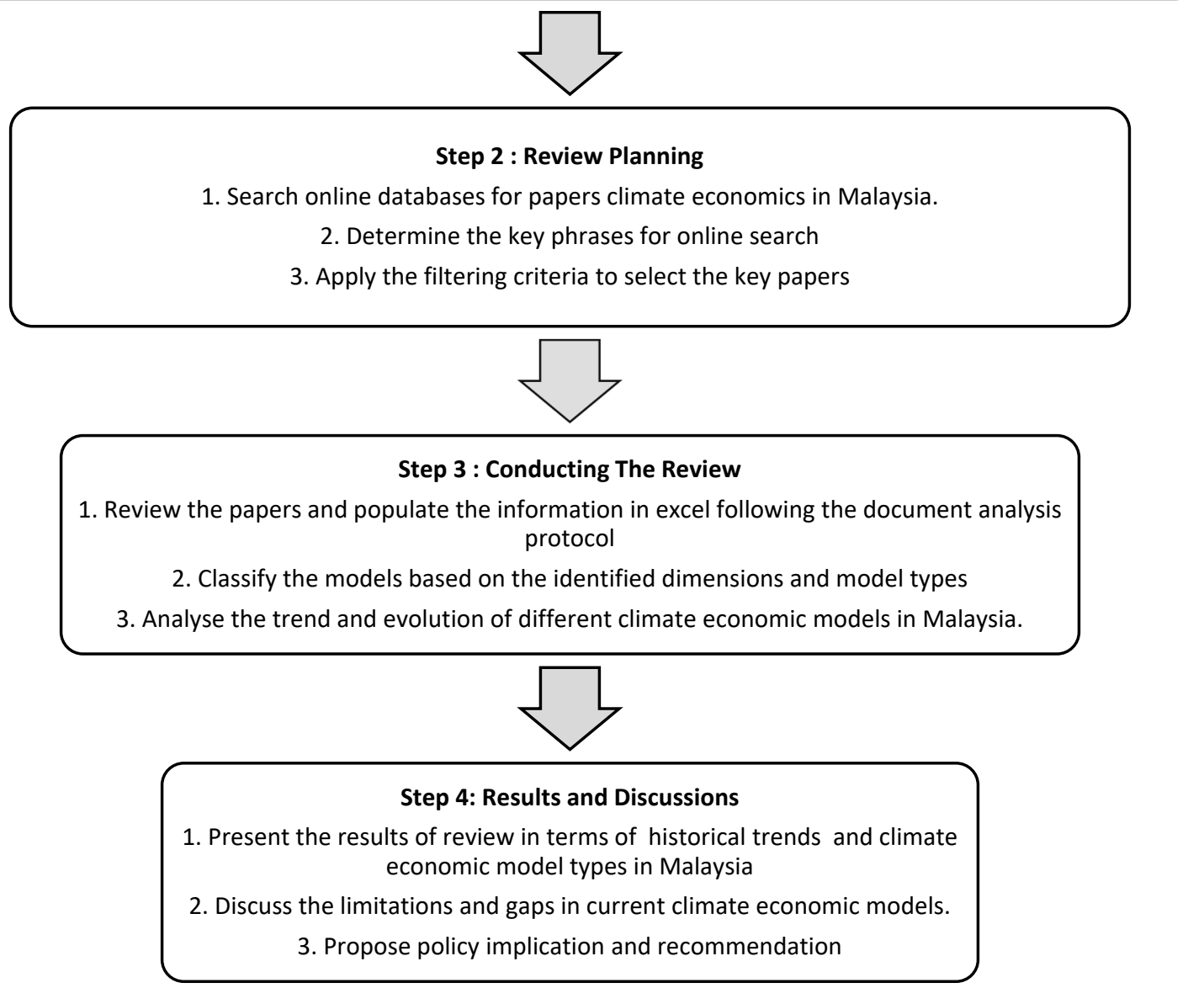

Figure 2. Systematic Review Method Used for Reviewing Climate Economic Models in Malaysia.

\section{An Overview of Global Efforts in Climate Economic Modelling}

Energy economics models were widely used to estimate the cost of GHG abatement prior to the advent of integrated climate economics models in the 1990s [20-23]. Nordhaus used an optimization model to determine the balance between the abatement cost and the cost of avoided damages from the physical impacts of climate change [24]. More climate-economic models such as DICE, PAGE \& FUND are developed in the past two decades to determine carbon pricing to correct the market failure $[25,26]$.

There was a surge in climate economic models since the early 1990s. This was motivated by the release of the first IPCC assessment report in 1990 [27] and the establishment of UNFCCC in 1992. Below is the description of three key climate economic models often quoted in IPCC assessment reports.

1. Dynamic Integrated Climate and Economy

Dynamic Integrated Climate and Economy or commonly known as DICE model evolved from previous works on energy models developed by William Nordhaus and gained more popularity during the early 1990s [21]. Regional Integrated Assessment Model or commonly known as the RICE model was developed during the mid-1990s to downscale the DICE to a regional-based analysis by William Nordhaus [28]. Both models are top-down 
assessment models often quoted in IPCC reports. DICE analyses at the global scale and RICE has the capability of analyzing at the regional scale [29].

2. Policy Analysis of Greenhouse Effect

Policy Analysis of Greenhouse Effect or commonly known as PAGE, was a model initiated to serve European Union decision-makers and was developed by Chris Hope in 1991 [30,31]. This is a top-down model used in various publications such as "The Stern Review" by Cambridge University. PAGE model is also used at the regional level [32]. This model analyzed climate economics at national levels as the non-market impacts vary widely between countries [33].

3. Climate Framework for Uncertainty, Negotiation, and Distribution

FUND or "Climate Framework for Uncertainty, Negotiation, and Distribution" was developed by Richard Tol in the early 1990s. This is to study the impact of climate policy on international capital transfers by clustering the worldwide economy into nine economic regions [34]. After version 2.5, the model subdivided the world into 16 regions (http: / / www.fund-model.org). Subsequently, FUND was widely referred to for climate policy discussions [35].

The economic models range from basic models incorporating principles of general equilibrium to complex algorithms, integrating climate science to determine the carbon price required to correct the externalities [36,37].

The carbon price is also sometimes referred to as the Social Cost of Carbon (SCC) which is the marginal benefit of GHG reduction by one tonne [38]. In other words, it is also an economic measurement of the impact of adding one more tonne of carbon dioxide equivalent $\left(\mathrm{CO}_{2} \mathrm{e}\right)$ commonly called GHGs. From the definition above, the unit of measurement for SCC can be both in tonnes of carbon dioxide $\left(\mathrm{CO}_{2}\right)$ or carbon dioxide equivalent $\left(\mathrm{CO}_{2} \mathrm{e}\right)$ depending on the framework and coverage of the model.

SCC is a function of climate damages quantified as global Gross Domestic Product (GDP) loss by IPCC reports [39,40]. The highest GDP impact was 3.5\% in IPCC 1996 compared to $20 \%$ in IPCC 2007. The estimates of the GDP impact of climate change in the second assessment report by IPCC are far lower than the fourth assessment report due to the early stage of climate economics modelling which only accounted for a gradual change in climate conditions on the market sectors of an economy. Catastrophic impacts such as abrupt changes in the frequency and intensity of extreme weather events and climate shocks (i.e., system change) or even non-market factors such as human health and environment were not factored [41]. The developing countries already suffer a higher degree of climate damage compared to the developed countries in the form of a market. Hence, including damage from climate shocks and non-market impact will make it worst [42-44]. The "Stern Review" run climate economic modelling using "Monte-Carlo" simulation technique indicates that the mean cost of climate change in developing countries such as India as well as South East Asia is approximately $6 \%$ of regional GDP by 2100 compared to global average GDP of $2.6 \%$ [5].

The latest IPCC Fifth Assessment Report reiterated that the impacts of climate change are real and strengthen the evidence that developing countries are more vulnerable to the impacts of climate change [6]. Since the cost of climate damages could be higher in developing countries, climate economic modelling will give value to the SCC. There is a need to downscale the climate economic models to understand the regional or even country-level impacts due to high uncertainty in global models [45]. The climate economic model will enable nations to determine appropriate SCC to correct the externalities of GHG emissions [42]. Many countries have introduced carbon pricing based on decades of negotiations and research findings (World Bank et al., 2016). Malaysia needs a comprehensive climate economic modelling to comprehend the short- and long-term impacts and make sound policies to build resilience and sustainability. 


\section{Identification of the Key Dimensions and a Framework to Classify Climate Economic Models}

Climate economic modelling can be viewed in two key dimensions namely "level of details" and "time". The first dimension can be from an economic or spatial details perspective modelling as a "top-down" or "bottom-up" approach [44]. Nordhaus [46] and Hope [47] worked on top-down models that include global or regional climate damage functions and they don't include spatial or economic structural details. However, the bottom-up models such as "IMAGE 2.0" [48] have good sectoral and spatial details but fail to capture aspects of adaptation and related welfare. Such bottom-up climate economics models contain too much information and it is difficult to interpret [44]. IMAGE models have been used widely to study the land use, agriculture economy, natural vegetation, hydrology, and other climate impacts closely linked to spatial parameters [49].

The second dimension is based on time. Climate models can be classified to fit the objectives of the short-term and long-term analysis. Input-Output (I-O) tables and Social Accounting Matrix (SAM) [50] models are generally short term [51]. These models are valid when the fundamental structure of the economy remains constant and assume advancement in low carbon technologies do not cause any change to economic structure. Most of these models took the carbon price as exogenous and analyze the impact on the current state of the economy in the short run [52]. They are also good for studies on tax neutrality which redistributes the collected carbon tax for social welfare [53].

Long term climate economics model incorporates the impact of climate change and its associated damage costs. The long-term models also factor in the possibility of changing economic structure due to the advancement of low carbon technology in terms of estimated cost reduction [54]. Such models integrating climate science and economy are called Integrated Assessment Models (IAMs) and they were studied from an aggregated view and mostly top-down models [51]. The IAM framework commonly includes the following common elements in the modelling:

- Projections of global and local temperatures

- Bounded scenarios with respect to changes in precipitation and storms

- Large scale systemic or surprise shocks to climate systems such as the shift of oceans circulation or sudden reversal of carbon sink in the biosphere

Comparatively, I-O and SAM based models are matured, however since their nature is to serve short term analysis, climate feedback loops that will be in long horizons cannot fit in. Thus, the carbon price is usually exogenous making the largest limitations for I-O or SAM based models. IAM based models are mostly top-down and the limitation is that they are not suitable for a bottom-up analysis looking into economic impacts by sectors in a region or country.

Hence, climate economic models from both dimensions of level and detail and time are required to complete the puzzle of SCC and its impact on the economy. IAM can cover both short-term and long-term analysis. However, these models have disadvantages, whereby they are unable to study in detail the economic impacts of different sectors within the economy [55]. The "bottom-up" models such as I-O or SAM can fulfill this gap, where they can give granularity to sectorial impact with less uncertainty which is suitable for short-term analysis. Figure 3 provides a framework to group the climate economics models into four quadrants for an easy understanding. 
Time Dimension

\begin{tabular}{c|c|c|c|}
\hline \multicolumn{1}{c}{ Time } \\
Dimension
\end{tabular}$\left\{\begin{array}{ccc|c|}\text { Short-Term } & \text { Long-Term } \\
\hline \text { Top-Down } & \begin{array}{c}\text { IAM (e.g. DICE, RICE, } \\
\text { PAGE, FUND) }\end{array} & \begin{array}{c}\text { IAM (e.g. DICE, RICE, } \\
\text { PAGE, FUND) }\end{array} \\
\hline \text { Bottom-Up } & \begin{array}{c}\text { I-O Analysis and SAM } \\
\text { based Models }\end{array} & \text { IMAGE Model } \\
\hline\end{array}\right.$

Figure 3. Framework to Group Climate Economics Models.

Based on the above framework and analysis key models are identified as I-O tables, SAM, and IAM. These three models can be used to classify and review climate economic modelling in Malaysia. The following section will analyze the key literature on the origin of climate economics in Malaysia.

\section{Trends and Developments of Climate Economic Modelling in Malaysia}

Climate change discussions have been a global debate since the establishment of IPCC in 1988. However, the involvement of the Malaysian government in global climate negotiations only started after Malaysia ratified the UNFCCC treaty on 13 July 1994. Malaysia subsequently ratified the Kyoto Protocol in Sept 2002 and the Paris Agreement in Nov 2016 respectively. Table 1 summarised three decades (1988-2020) of the history of developments in climate economics in Malaysia into four time-frames of Periods 1 to 4 .

Table 1. Highlights of Climate Economics and Carbon Pricing in Malaysia (1988-2020).

\begin{tabular}{ll}
\hline \multicolumn{1}{c}{ Time-Frames } \\
\hline Period 1 (1988-2004) \\
- IPCC (1988) \\
- $\quad$ KNFCCC (1992) \\
\hline
\end{tabular}

\section{Period 2 (2005-2012)}

- $\quad$ First Phase of Kyoto Protocol Commitment period
- CGE market-based models \& IAMs were developed for global and developed countries. No published climate economic modelling activity was recorded in Malaysia.

- Carbon price or any economic mechanisms were not clearly presented in the National Climate Change Policy. The policy vaguely mentioned market mechanisms to promote a low carbon economy under Key Actions 6-Strategic Thrust 2 [56].

- $\quad$ Academic discussion papers started to emerge post-National Climate Change Policy [57].

- UNDP launched a project on the Economic of Climate Change that identified the need to have a CGE analysis for estimating the cost of climate change. PAGE 2009 was used [58].

\section{Period 3 (2012-2016)}

- $\quad$ Start of Second Phase of Kyoto Protocol Commitment Period (2012)

- $\quad$ Paris Agreement into force (2016)

\section{Period 4 (2017-2020)}

- $\quad$ Post Paris Agreement came into force (2017-2020)
- Various methods using basics of I-O models [59,60], Social Accounting Matrix [61] \& IAMs emerged [62,63].

- Carbon price modelling becomes an interest in academia in Malaysia and was publicly discussed in local news [64].

- The Malaysian INDC submitted to the Paris Agreement treaty only indicated that the Malaysian government will not use international carbon market mechanisms to meet the voluntary obligation. No indication of applying any carbon pricing or trading mechanisms in NDC [65].

- Universities and NGOs started to give comprehensive proposals to the government $[15,66]$ and Malaysia news capturing intellectual debates in budget proposals [67].

- 5-year economic plans [68] and 2050 long term roadmaps [69] have started to consider carbon tax on the horizon as more neighbouring ASEAN countries have implemented such schemes. For example, Singapore implemented carbon tax in 2019 and disclosed in NDC submission to UNFCCC [70]. Thailand and Vietnam [71] considering implementing carbon trading systems [72].

Research in climate-related to CGE modelling picked up momentum globally from 2002-2008 [73]. The published papers increase fivefold during 2009-2015 [73]. This concurs with Period 1 and 2 in this review.

The above analysis indicates that the discussion on climate economics in Malaysia gained momentum in Period 2 (2005-2012) after the introduction of the National Climate Policy in 2009. The initial work was in the academic circles. The carbon price was intro- 
duced as an exogenous parameter into modelling approach build based on I-O table by the academia [57]. However, the momentum in academia was not translated into actual GHG reductions. It was reported that Malaysia has not reduced its $\mathrm{CO}_{2}$ intensity per unit of GDP from 1991 to 2013 [74].

Climate economics modelling work was further explored in Period 3 by using SAM as well as IAMs as shown in Table 2. However, this work was not at the centre stage for decision making during the ratification of the Paris Agreement in 2016. The reflection is seen from a modest Malaysia National Determined Contribution (NDC) which was not too ambitious. It is also important to note that, Malaysia's modest ambition is also a reflection of collective global NDC submissions [75].

In the post-Paris Agreement in Period 4, many jurisdictions and countries around the world have implemented or scheduled to implement carbon pricing initiatives [72]. However, carbon price is still at the level of academic discussion, proposals, and plans at various levels of civil society and government departments in Malaysia. No firm date for the implementation is seen in Malaysia.

This, the work on climate economics modelling has become more relevant to promote sound carbon pricing policies in Malaysia in Period 4 and beyond.

\section{Classification of Climate Economic Modelling in Malaysia}

A review was conducted to classify climate economics-related papers in Malaysia from Period 2 to Period 4. A total of 31 papers related to climate economics discussion in Malaysia were reviewed. Discussion on climate economics in Malaysia varies from sectorial energy modelling focusing on renewables [76,77], transport [78], agriculture [79-81], and urbanisation [82]. Some literature discussed Malaysia in general but focusing on ASEAN [83,84].

A total of 22 papers that discussed climate economics or carbon pricing in Malaysia were filtered. The remaining 9 papers were filtered out as they do not discuss carbon pricing or specific on Malaysia. The selected papers are summarized in Appendix A. These papers include those that used models of I-O tables, SAM, IAMs, and some review papers or policy discussions on carbon pricing. None of the papers employed IMAGE modelling in Malaysia. An additional category of review papers was included in this study due to several review or policy papers related to climate economics published in Malaysia during the period of study. Figure 4 shows the distribution of papers from 2009-2020.

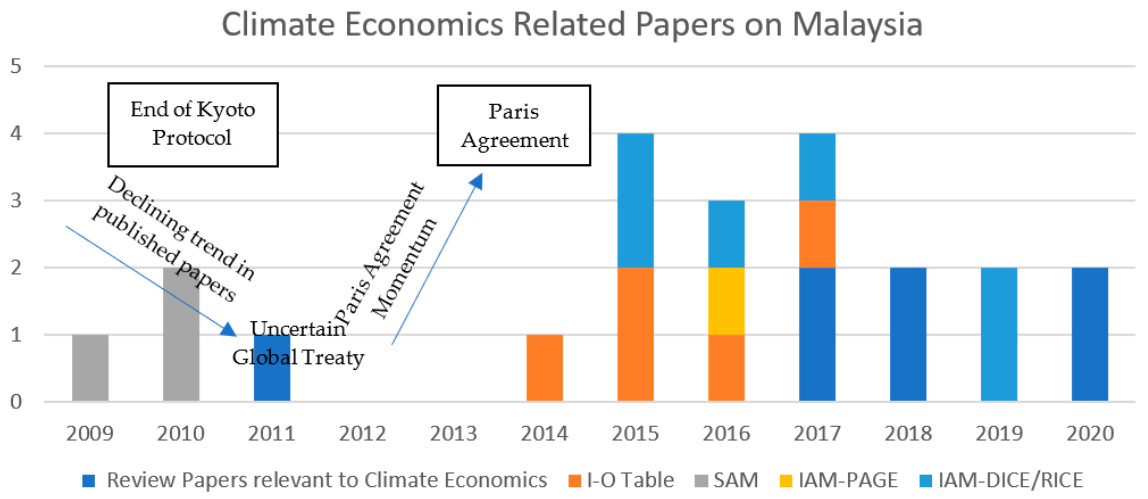

Figure 4. Climate Economics Related Papers in Malaysia.

The first paper on climate economics modelling in Malaysia was published in 2009 [85]. The authors employed SAM modelling to investigate the short-term analysis of carbon tax injection into Malaysian economy. The authors conclude that the introduction of carbon price in the form of tax will reduce $\mathrm{CO}_{2}$ emissions but at the same time will have a negative impact on the GDP. Two similar studies were published in 2010 based on the SAM modelling by the same authors with updated data. The studies inferred that imposing a price on carbon will have a negative impact on GDP. In 2011, a policy review paper by Al- 
Amin was motivated by National Climate Change Policy and Malaysia voluntary pledge at the Copenhagen conference to reduce GHG intensity [86]. There were no published papers on Malaysian climate economics modelling in 2012 and 2013. Malaysia actively participated in Kyoto Protocol Clean Development Mechanism (CDM) during the first commitment period of 2008-2012 [86,87]. The declining trend of published papers on climate economics modelling in Malaysia could be largely attributed to the uncertainty on the second phase of Kyoto Protocol and a new global treaty on climate change. An increasing trend in published papers related to climate economics modelling in Malaysia was observed after 2014. This can be attributed to the momentum of securing a global deal on climate change which was a reality with a landmark Paris Agreement in 2015 [88]. More steady publications are seen in Figure 4, post INDC announcement by Malaysia government in 2015 [65] as well as the IPCC 1.5 degrees special report [89] on the need for unprecedented action to get to net-zero by 2050. More climate economics modeling is needed in Malaysia to meet the global goals of climate change. The previous works on climate economics in Malaysia need to be properly categorized for further analysis.

Thus, the published papers were categorized into five broad groups according to their objective of the paper and their modelling approach which can be grouped into four quadrants as discussed in this paper before. The five broad groups are as follows:

1. Group 1: I-O Tables Models

Modelling could be linear using block equations and good for short term analysis assuming no major change to the current economic structure in the form of I-O tables for economy-wide or sector-specific. Suitable to study the impact on current GDP impact of introducing carbon tax.

\section{Group 2: SAM Models}

Modelling papers used Social Accounting Matrices to study the impact of carbon tax in the short run as well to economy-wide or sector-specific in a non-linear approach.

\section{Group 3: IAM-PAGE Models}

Models integrate climate science and economy for the long run in a nonlinear approach as used in the Stern Review [33]. Long term climate feedbacks are considered in models to optimize the goal of GHG reduction and limiting temperature increase. Good for an economy-wide impact study. This model is often quoted in IPCC literature for climate economics.

\section{Group 4: IAM- DICE/RICE Models}

Models integrate climate science and economy for long-run analysis in a nonlinear approach as used by Nordhaus [90]. Have the same advantages as IAM-PAGE model. This model is also often quoted in IPCC literature for climate economics.

5. Group 5: Policy review papers with no modelling

No modelling was done and mostly discuss the policy and simple analysis. Provides current state of policy overview and clearer problem statement for future work on climate economics modelling.

Almost one-third of the papers over the past decade were based on I-O and SAM models accounting for $23 \%$ and $14 \%$, respectively. DICE/RICE models accounted for $27 \%$ and IAM-PAGE models accounted for $4 \%$. Review papers accounted for the remaining $32 \%$ of climate economics modelling papers. Collectively, $68 \%$ of the papers were based on climate economics modelling as shown in Figure 5. 


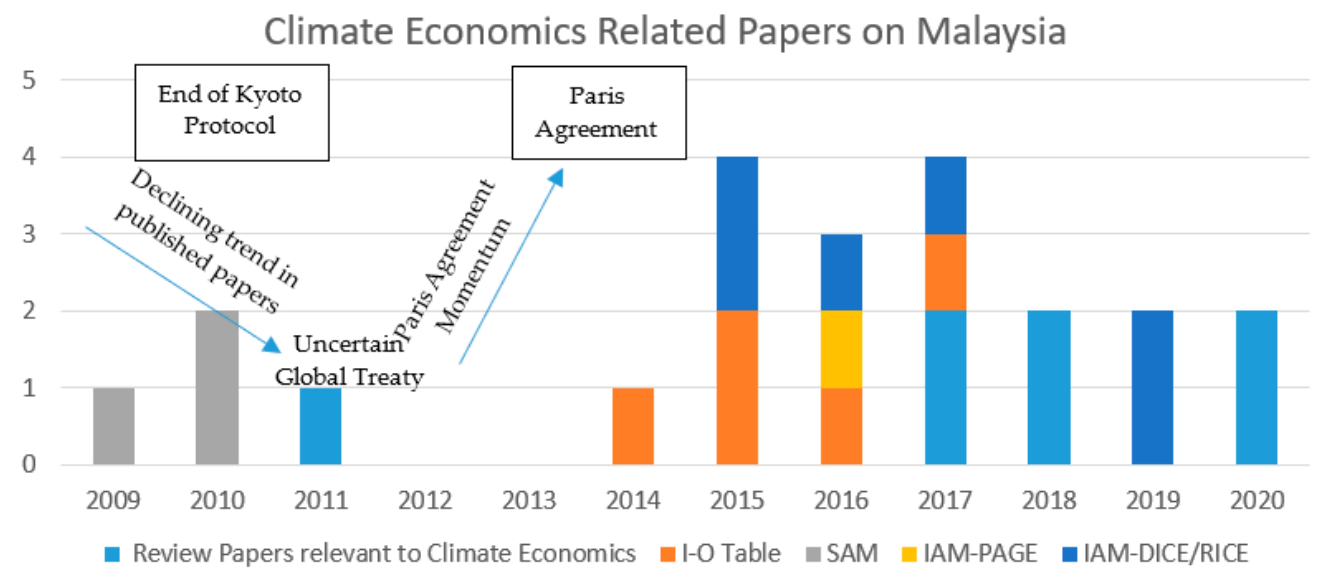

Figure 5. Types of Climate Economics Papers on Malaysia.

\section{Limitations and Gaps in Current Climate Economic Models}

Further analysis of climate economics papers was conducted to identify the limitations of each climate economic models in Malaysia. The gaps identified were categorized for further improvement. The climate economics papers were analyzed using the five groups discussed in the earlier section and results are shown in Table 2.

Table 2. Analysis of Climate Economic Papers in Malaysia.

\begin{tabular}{|c|c|c|c|c|c|c|}
\hline \multicolumn{2}{|c|}{ Model Dimensions } & \multirow{2}{*}{$\begin{array}{l}\text { Type of } \\
\text { Models }\end{array}$} & \multirow{2}{*}{\multicolumn{2}{|c|}{ Key Contributors }} & \multirow{2}{*}{$\begin{array}{c}\text { Summary of Carbon Price } \\
\text { Discussions }\end{array}$} & \multirow[b]{2}{*}{ Identified Limitations } \\
\hline $\begin{array}{l}\text { Level of } \\
\text { Detail }\end{array}$ & Time & & & & & \\
\hline $\begin{array}{l}\text { Bottom-up by } \\
\text { economic } \\
\text { sectors }\end{array}$ & $\begin{array}{l}\text { Short term } \\
\text { analysis }\end{array}$ & $\begin{array}{l}\text { I-O } \\
\text { Tables }\end{array}$ & $\begin{array}{l}1 . \\
2 . \\
3 .\end{array}$ & $\begin{array}{l}\text { Othman \& } \\
\text { Yahoo [91,92] } \\
\text { Solaymani [93] } \\
\text { Othman \& } \\
\text { Jafari [59] }\end{array}$ & $\begin{array}{l}\text { - Carbon price is used in } \\
\text { simultaneous block } \\
\text { equation for simulation. } \\
\text { Carbon price is exogenous } \\
\text { and injected a value based } \\
\text { on international literature. } \\
\text { - Commonly concludes that } \\
\text { that carbon tax is good to } \\
\text { reduce } \mathrm{CO}_{2} \text { but will impact } \\
\text { GDP negatively. }\end{array}$ & $\begin{array}{l}\text { - Considers energy-related } \\
\mathrm{CO}_{2} \text { emissions only. } \\
\text { Not suitable for long term } \\
\text { analysis as the economic } \\
\text { structure will change due to } \\
\text { technology advancements. } \\
\text { Other sectors emitting GHG } \\
\text { emissions as per IPCC } \\
\text { categories are not modelled. }\end{array}$ \\
\hline $\begin{array}{l}\text { Bottom-up by } \\
\text { economic } \\
\text { sector }\end{array}$ & $\begin{array}{l}\text { Short term } \\
\text { analysis }\end{array}$ & $\begin{array}{l}\text { SAM } \\
\text { simultane- } \\
\text { ous block } \\
\text { equation } \\
\text { simulation }\end{array}$ & $\begin{array}{l}1 . \\
2 .\end{array}$ & $\begin{array}{l}\text { Al-Amin } \\
{[85,94]} \\
\text { Abdul Hamid } \\
{[95]}\end{array}$ & $\begin{array}{l}\text { Carbon price is exogenous } \\
\text { and injected a value based } \\
\text { on international literature. } \\
\text { SAM was built and papers } \\
\text { commonly demonstrate that } \\
\text { recycling of carbon tax } \\
\text { revenue to support social } \\
\text { well-being reduces } \mathrm{CO}_{2} \\
\text { emissions and improves } \\
\text { GDP marginally. }\end{array}$ & $\begin{array}{l}\text { - } \begin{array}{l}\text { Only considers } \\
\text { energy-related } \mathrm{CO}_{2} \\
\text { emissions. }\end{array} \\
\text { Not suitable for long term } \\
\text { analysis integrating climate } \\
\text { science. } \\
\text { Other sectors emitting GHG } \\
\text { emissions as per IPCC } \\
\text { categories are not modelled. }\end{array}$ \\
\hline
\end{tabular}


Table 2. Cont.

\begin{tabular}{|c|c|c|c|c|c|c|}
\hline \multicolumn{2}{|c|}{ Model Dimensions } & \multirow{2}{*}{$\begin{array}{l}\text { Type of } \\
\text { Models }\end{array}$} & \multirow[b]{2}{*}{ Key Contributors } & \multirow{2}{*}{\multicolumn{2}{|c|}{$\begin{array}{l}\text { Summary of Carbon Price } \\
\text { Discussions }\end{array}$}} & \multirow[b]{2}{*}{ Identified Limitations } \\
\hline $\begin{array}{l}\text { Level of } \\
\text { Detail }\end{array}$ & Time & & & & & \\
\hline \multirow[b]{2}{*}{$\begin{array}{l}\text { Top-down by } \\
\text { economy-wide }\end{array}$} & \multirow[b]{2}{*}{$\begin{array}{l}\text { Short \& } \\
\text { long-term } \\
\text { analysis }\end{array}$} & \multirow[b]{2}{*}{$\begin{array}{l}\text { IAM- } \\
\text { PAGE }\end{array}$} & \multirow[b]{2}{*}{$\begin{array}{l}\text { 1. Wong } \\
{[54,62,96]}\end{array}$} & \multicolumn{2}{|c|}{$\begin{array}{l}\text { A carbon price of } 33.3 \text { to } \\
68.4 \text { USD/ tonne } \mathrm{CO}_{2} \mathrm{e} \text { was } \\
\text { proposed for } 2020 \text { and } 100.9 \\
\text { to } 225.1 \text { USD / tonne } \mathrm{CO}_{2} \mathrm{e} \\
\text { was proposed for } 2050 \text { for } \\
\text { two different scenarios: }\end{array}$} & \multirow[b]{2}{*}{$\begin{array}{l}\text { - Not suitable to analyze } \\
\text { sector-specific impact. } \\
\text { The model assumes the } \\
\text { same scenarios for the } \\
\text { whole world which might } \\
\text { not be the case. }\end{array}$} \\
\hline & & & & (a) & $\begin{array}{l}\text { Baseline: IPCC } \\
\text { Special Report on } \\
\text { Emission Scenarios } \\
\text { (SRES)- A1B. } \\
\text { Low emission } \\
\text { scenario which } \\
\text { peaks in } 2016 \text { and } \\
\text { gradually reduce } \\
5 \% \text { p.a. with } 50 \% \\
\text { chance of limiting } \\
\text { global temperature } \\
\text { increase to } 2 \text { deg C. }\end{array}$ & \\
\hline
\end{tabular}

- $\quad$ Based on the top-down model used by William Nordhaus. Published papers in Malaysia downscaled the model to a regional level with Malaysia's temperature, population, and GDP.

- $\quad$ Simulates a wide range of carbon prices using different scenarios updated based on IPCC reports release.

- Initial papers in 2015 set the carbon price from 145 $\mathrm{RM} / \mathrm{tCO}_{2}$ and the upper limit up to $845 \mathrm{RM} / \mathrm{tCO}_{2}$ following international literature [98].

1. Al-Amin

2. Rasic

analysis
$[84,98,99]$

3. Ahmed [100]

4. Sarkar [101]
- A paper in 2019 Assumes a price of $\mathrm{RM} 130 \mathrm{RM} / \mathrm{tCO}_{2}$ for the model and proposed a price less than $100 \mathrm{RM}$ $/ \mathrm{tCO} 2$ before 2020 and goes up to $500 \mathrm{RM} / \mathrm{tCO}_{2}$ beyond 2080(A. Ahmed et al., 2019).

- $\quad$ Another paper in 2019 gives a carbon price range from 44 to $97 \mathrm{RM} / \mathrm{tCO}_{2}$ for various scenarios [102].

\begin{tabular}{|c|c|c|c|c|c|c|}
\hline $\begin{array}{l}\text { Economy- } \\
\text { Wide }\end{array}$ & $\begin{array}{l}\text { Short \& } \\
\text { long-term } \\
\text { analysis }\end{array}$ & $\begin{array}{c}\text { Policy } \\
\text { review } \\
\text { where } \\
\text { no } \\
\text { modelling } \\
\text { involved. }\end{array}$ & $\begin{array}{l}1 . \\
2 . \\
3 .\end{array}$ & $\begin{array}{l}\text { Al-Amin [57], } \\
\text { Alasinrin [73], } \\
\text { Wong [97] }\end{array}$ & $\begin{array}{l}\text { Discusses the need to have } \\
\text { more economic modelling, } \\
\text { and carbon price to drive } \\
\text { GHG emission reductions. }\end{array}$ & - No empirical analysis. \\
\hline
\end{tabular}

The limitation in the climate economic models in Table 3 needs continuous improvement. There are common limitations even though the dimension and purpose of the models vary. The limitations can be clustered and presented as key gaps in climate economic modelling in Malaysia. The three key gaps identified can be clustered as follows: 
1. Economic Sector: Inclusion and coverage of the economic sector in the modelling framework aligning to the Malaysia Third National Communication Report to UNFCCC

2. Type of GHGs: Inclusion and coverage of seven types of GHG as per IPCC 2006 guidelines

3. Climate Damage Element: Inclusion and coverage of climate damage function or cost in the modelling framework

Table 3. Key Gaps in Climate Economics Modelling in Malaysia.

\begin{tabular}{|c|c|c|}
\hline $\begin{array}{l}\text { Key Gap } \\
\text { Clusters }\end{array}$ & $\begin{array}{l}\text { Bottom-Up and Short-Term Analysis Models } \\
\text { (I-O Table /SAM Based Models) }\end{array}$ & $\begin{array}{l}\text { Top-Down and Long-Term Models } \\
\text { (Integrated Assessment Models: PAGE, DICE/RICE) }\end{array}$ \\
\hline Type of GHGs & $\begin{array}{r}\text { Only carbon dioxide emission is modelled in all modelling work } \\
\text { Communications report are omitted in the modelling as well [1: } \\
\text { Hydrofluorocarbon (HFCs), Perfluorocarbons (PFCs) }\end{array}$ & $\begin{array}{l}\text { Other six GHGs in classified in IPCC [102] and Malaysia Third National } \\
\text { The other six omitted GHGs are Methane }\left(\mathrm{CH}_{4}\right) \text {, Nitrous Oxide }\left(\mathrm{N}_{2} \mathrm{O}\right) \text {, } \\
\text { Sulphur Hexafluoride }\left(\mathrm{SF}_{6}\right) \text {, and Nitrogen Trifluoride }\left(\mathrm{NF}_{3}\right) \text {. }\end{array}$ \\
\hline Economic Sector & $\begin{array}{l}\text { These models have flexibility and studies have covered both } \\
\text { economy-wide and sector-specific analysis. } \\
\text { GDP impact from the introduction of carbon tax on the energy and } \\
\text { transportation sector is mostly discussed. } \\
\text { The impact of carbon tax on agriculture, land, and forestry is not } \\
\text { well discussed. }\end{array}$ & $\begin{array}{c}\text { IAM models incorporate climate science and economy. } \\
\text { However, most of the analysis and modelling focusing on the energy } \\
\text { sector. } \\
\text { Agriculture, Land Use Land Use Change and Forestry (LULUCF), Waste, } \\
\text { Industrial Processes \& Product Use (IPPU) are not considered in all } \\
\text { modelling. These sectors are part of the INDC and national GHG } \\
\text { inventory [12]. } \\
\text { Carbon Sink is not factored in all modelling. Carbon sink is key in } \\
\text { determining the net GHG emissions as they offset the GHG emissions by } \\
\text { other sectors and supports the pathways to 1.5-degree world from a } \\
\text { Natural Climate Solutions angle [89]. }\end{array}$ \\
\hline $\begin{array}{l}\text { Climate Damage } \\
\text { Element }\end{array}$ & $\begin{array}{l}\text { I-O or SAM models do factor the damages from the impact of } \\
\text { global temperature rise and climate change due to the nature of } \\
\text { the models to serve short-term analysis. }\end{array}$ & $\begin{array}{c}\text { Malaysia temperatures and other meteorological information are used in } \\
\text { the models. } \\
\text { However, coefficients for damage functions for IAM are not calibrated to } \\
\text { reflect Malaysia conditions. The impacts of climate change are not } \\
\text { uniform. IPCC reports have indicated that developing countries are more } \\
\text { vulnerable compared to developed countries [39]. Thus, climate } \\
\text { economics models need to localize the climate damage functions to have } \\
\text { a more realistic economic impact study. }\end{array}$ \\
\hline
\end{tabular}

The key gaps are elaborated in the context combined dimensions of "Bottom-Up and Short-Term Models" as well as "Top-Down and Long-Term Models" as shown in Table 3.

The first group of I-O tables and SAM models were the initial climate economics models used in Malaysia. The models focused on the short-term impact on economic sectors in Malaysia by injecting exogenous carbon price into the economy. These models were robust in modelling the carbon tax neutrality concept. However, the models were not suitable to analyze the long-term impacts of climate change as they cannot factor long term feedback loops of climate change and its associated damage cost. I-O and SAM models used in Malaysia could not capture the potential transition towards a low carbon economy due to progress in technology \& innovation.

The second group of IAM models only emerge after the post-Paris agreement in 2015. The IAM models were more robust to analyze the long-term impact of global temperature increase, incorporate the factor of technology advancement in climate mitigation and calibrate damage cost, and its impact on Malaysia economy. The required carbon price to delay or even reduce the impact of climate change can be determined by IAM models downscaled to the country-specific climate and economic parameters. These models are best suited to determine the social cost of carbon required to correct market failure due to the negative externality of global warming and climate change.

However, there are some limitations identified in both groups of climate economic models in Malaysia and the limitations of each model can be summarised into three key gap clusters. The first key gap centered on the type of GHGs modelled which is limited to carbon dioxide only and the remaining six GHGs are omitted from modelling. The second key gap focussed on GHG emissions sector coverage. The energy sector is covered extensively by all models. However, other sectors such as the industrial process, land use, agriculture and forestry were not extensively covered. The third gap is on climate damages. The I-O tables and SAM models do not include climate damage function in the analysis. The IAM group of models included the damage function however the parameters 
were not localized to reflect local climate hazards and vulnerability suited to Malaysia geography and economy.

\section{Policy Implication and Recommendation}

Current efforts by the Malaysian government in ratifying the Paris agreement and committing to a Nationally Determined Contribution (NDC) is commendable [65]. The National Policy on Climate Change released in 2009 serves as a backbone in shaping future climate mitigation and adaptation actions. However, any policy interventions on these climate actions will have economic implications. Climate economic modelling will help to answer the questions on both short- and long-term implications and pave the path for innovative solutions to reduce or even eliminate negative implications. It is logical for bottom-up climate models to focus on short-term economic analysis as they are meant to analyze sectoral impacts assuming no change in economic structure. It is not possible to include the long-term impacts of climate change in these models. These models are perfect to study the sectorial impacts of introducing carbon tax or emission trading schemes in short term. However, if these models do not address the key gaps clusters highlighted in this paper, there will be inaccuracy in estimating the implication economy-wide both in the short term and long-term.

The level of carbon price is determined by the amount of efforts required to reduce GHG emissions. Malaysia is blessed with tropical rainforest including coastal biodiversity such as mangrove areas which serves as a huge carbon sink [103]. Ignoring this sector in the climate economic modelling will result in overestimates of the required efforts to reduce GHG emissions as the net impact of carbon emissions and sinks are not taken into consideration in the modelling work. This will lead to a higher price on carbon to mitigate the externalities of global warming and climate change. Subsequently, a high carbon price will increase the cost of production and thus Malaysian products and services will become less competitive in the global market.

Short-term models that do not consider long-term climate feedbacks will underestimate the economic impact and ignore the need for a rapid shift to a low carbon economy. Thus, short-term models require exogenous carbon price from long term climate economic models to study the sectorial implication and design the right policy interventions.

Climate economic model not covering all types of GHGs will create serious implications on the economy as well as the environment with non-encompassing policy decisions. For example, 23\% of Malaysia's national GHG inventory is methane [104]. Ignoring the methane $\left(\mathrm{CH}_{4}\right)$ in modelling and policy decision could lead to inefficiency in the energy industry including during production of oil and gas as well as power generation, mismanagement of methane emissions in landfills and sewerage treatment as well as in the Agriculture, Land Use Land Use Change and Forestry (LULUCF) sectors covering palm oil and peatland issues. In a long run, failure to manage methane today will lead to accelerated climate change impacts as methane is 80 times more potent than carbon dioxide using a 20 years global warming potential reference [105]. Malaysia will have to put more money into adapting to the physical impacts of climate change such as floods and droughts which will have an impact on agriculture yield and eventually a risk to the economy and food security [106].

Policy decisions with climate economic modelling did not include the climate damage functions that might overlook the cost of adaptation and lead to an inaccurate forecast of GDP growth and social welfare. The global climate economic modelling results may vary between regions or countries [107]. Poor or developing countries may suffer higher GDP losses [5]. It is important to downscale the global IAM models to study the regional or even country-specific cost of climate change and GDP impact to determine the appropriate carbon price to correct the market failure due to negative externalities of GHG emissions. Thus, it is recommended for the integrated assessment models to calibrate the damage functions to be specific to the climate hazards to which the Malaysian economy is vulnerable to adequately assess the climate risk focusing on the geography of Malaysia. 


\section{Conclusions}

It is evident that climate change is real and carbon price needs to be introduced into the economy to correct the negative externalities of global warming and its impacts from climate change. Global climate economic models are available and categorised into two dimensions according to the methodology adopted in this review. The first dimension is based on the 'level of detail' which is subdivided into top-down and bottom-up approaches. The second dimension is based on the results of models to fit for 'time' of analysis in the long and short term. Climate economic modelling covering top-down, bottom-up, short and long-term analysis is important to draw effective policies and design appropriate interventions along the pathway to net-zero by 2050 as called by the IPCC special report on 1.5 degrees Celsius.

This review indicates that climate economic models used in Malaysia from 2009 to 2020 can be clustered into a first group using the bottom-up approach for short-term analysis and the second group using the top-down approach for long-term analysis. The first group is based I-O table and SAM model where they are applicable only for situations without a major change in economic structure. The second group of Integrated Assessment Models (IAM's) particularly PAGE, DICE, and RICE models are suited for long-term and top-down analysis integrating possible changes to world climate and economic systems. Forty-eight percent $(48 \%)$ of the papers reviewed were from the first group using I-O or SAM models and $35 \%$ from the second group using IAM models. The balance $17 \%$ are policy review papers highlighting the need to have a carbon price, but no modelling was done. IAM models provide the estimated exogenous carbon price levels required to decarbonize and prevent catastrophic climate events and damages. While I-O table and SAM models can use the exogenous carbon price recommended from IAM models to study the short-term economy-wide or sector-specific impact. I-O table or SAM models can also study to smooth out the implementation of carbon pricing by applying carbon tax neutrality methods.

Nearly a decade of climate economic modelling in Malaysia serves as a strong foundation for further improvement in both groups discussed above. This study identifies three key gaps clusters in both groups of climate economic models for further improvement. The first gap is on limited coverage of all types of GHG's reported to UNFCCC. The second gap is on non-inclusion of all GHG emission sectors as per the IPCC guidelines and the final gap is on non-inclusion of climate damage cost specific to Malaysia. The largest policy implication of not addressing the three key gaps in climate economic modelling will be the underestimation of climate change's impact on the economy and welfare of people in Malaysia. Setting the right social cost of carbon is crucial to managing GHG emissions in Malaysia and across the world. Climate economic models need to include all significant GHGs such as carbon dioxide as well as methane in the modelling covering all sectors contributing to GHG emissions as well as the sinks. Underestimating the damage from climate change and the cost of adaptation may impact economic growth. Overpricing of carbon will make Malaysian products and services not competitive. Thus, it is important to determine the gradual escalation of the carbon price to an appropriate level to make the Malaysian to grow sustainably and prevent future catastrophic impacts of climate change.

As an overall conclusion, climate economic modelling in Malaysia is still at the infant stage and the gaps in both groups of I-O table or SAM and IAM climate economic modelling need to be addressed urgently. This is possible by critically exploring and encouraging climate economic modelling research to make sound climate-related policies and interventions. The informed decision-making process with empirical studies on climate economics will pave the path towards a low carbon economy and sustainable development for private and public benefit to both Malaysia and the world as the climate is a global common good.

Author Contributions: Conceptualization, T.R.; methodology, T.R.; formal analysis, T.R.; data curation, T.R.; writing—original draft preparation, T.R.; writing—-review and editing, S.I.M.; visualization, T.R.; supervision, S.I.M. All authors have read and agreed to the published version of the manuscript. 
Funding: This research received no external funding.

Institutional Review Board Statement: Not applicable.

Informed Consent Statement: Not applicable.

Data Availability Statement: The data presented in this study are available on request from the corresponding author. The data are not publicly available due to restrictions on right of privacy.

Acknowledgments: The authors recognize the contribution of climate economic modelling work by great minds in Malaysia and across the world. The authors acknowledge Universiti Tenaga Nasional, Malaysia for the publication support.

Conflicts of Interest: The authors declare no conflict of interest.

\section{Appendix A}

Table A1. Shortlisted Climate Economic Papers on Malaysia.

\begin{tabular}{|c|c|c|c|c|}
\hline Year & Author & Name of Article & $\begin{array}{l}\text { Thematic } \\
\text { Focus }\end{array}$ & Journal \\
\hline 2009 & $\begin{array}{l}\text { Jaafar Abdul Hamid, } \\
\text { Al-Amin Abul Quasem } \\
\text { Siwar, Chamhur. }\end{array}$ & $\begin{array}{l}\text { Computable General Equilibrium } \\
\text { Techniques for Carbon Tax Modelling }\end{array}$ & Short-term, bottom-up & $\begin{array}{l}\text { American Journal of } \\
\text { Environmental Sciences }\end{array}$ \\
\hline 2010 & $\begin{array}{l}\text { Jaafar Abdul Hamid, } \\
\text { Al-Amin Abul Quasem, } \\
\text { Siwar Chamhur. }\end{array}$ & $\begin{array}{l}\text { A CGE analysis of the economic impact } \\
\text { of output- specific carbon tax on the } \\
\text { Malaysian economy }\end{array}$ & Short-term, bottom-up & $\begin{array}{l}\text { International Journal of } \\
\text { Environmental Sciences }\end{array}$ \\
\hline 2010 & $\begin{array}{l}\text { Jaafar Abdul Hamid, } \\
\text { Al-Amin Abul Quasem, } \\
\text { Siwar Chamhur. }\end{array}$ & $\begin{array}{l}\text { Climate change mitigation and policy } \\
\text { concern for prioritization }\end{array}$ & Short-term, bottom-up & $\begin{array}{c}\text { International Journal of } \\
\text { Climate Change Strategies } \\
\text { and Management }\end{array}$ \\
\hline 2011 & $\begin{array}{l}\text { Al-Amin Abul Quasem, } \\
\text { Walter Leal Filho, }\end{array}$ & $\begin{array}{l}\text { An overview of prospects and challenges } \\
\text { in the field of climate change in Malaysia }\end{array}$ & $\begin{array}{l}\text { Review } \\
\text { Paper }\end{array}$ & $\begin{array}{l}\text { International Journal of } \\
\text { Global Warming }\end{array}$ \\
\hline 2011 & $\begin{array}{l}\text { Al-Amin Abul Quasem, } \\
\text { Azam Mohammad Nurul, } \\
\text { Kari Fatimah, } \\
\text { Filho Walter Leal. }\end{array}$ & $\begin{array}{l}\text { Assessing the Scenario Concerning } \\
\text { Environmental Sustainability in Malaysia }\end{array}$ & Short-term, bottom-up & Scientific Research and Essays \\
\hline 2015 & $\begin{array}{l}\text { Masoud Yahoo, } \\
\text { Jamal Othman. }\end{array}$ & $\begin{array}{l}\text { Carbon and energy taxation for } \mathrm{CO}_{2} \\
\text { mitigation: a CGE model of the Malaysia }\end{array}$ & Short-term, bottom-up & $\begin{array}{l}\text { Environment, Development } \\
\text { and Sustainability }\end{array}$ \\
\hline 2015 & $\begin{array}{c}\text { Saeed Solaymani, } \\
\text { Roozbeh Kardooni, Sumiani Binti Yusoff, } \\
\text { Fatimah Kari. }\end{array}$ & $\begin{array}{l}\text { The impacts of climate change policies on } \\
\text { the transportation sector }\end{array}$ & Short-term, bottom-up & Energy \\
\hline 2015 & $\begin{array}{l}\text { Al-Amin Abul Quasem, } \\
\text { Rajah Rasiah, } \\
\text { Santha Chenayah. }\end{array}$ & $\begin{array}{l}\text { Prioritizing climate change mitigation: } \\
\text { An assessment using Malaysia to reduce } \\
\text { carbon emissions in future }\end{array}$ & Long-term, top down & $\begin{array}{l}\text { Environmental Science and } \\
\text { Policy }\end{array}$ \\
\hline 2015 & $\begin{array}{l}\text { Al-Amin Abul Quasem, } \\
\text { Rajah Rasiah, } \\
\text { Nazia Mintz Habib. }\end{array}$ & $\begin{array}{c}\text { Greenhouse Gas Reduction Options: } \\
\text { Towards a Climate Control Roadmap for } \\
\text { Malaysia }\end{array}$ & $\begin{array}{l}\text { Long-term, } \\
\text { top down }\end{array}$ & $\begin{array}{l}\text { Science and Technology } \\
\text { Trends }\end{array}$ \\
\hline 2016 & $\begin{array}{l}\text { Kum Yeen Wong, } \\
\text { Joon Huang Chuah, } \\
\text { Chris Hope. }\end{array}$ & $\begin{array}{l}\text { Carbon taxation in Malaysia: insights } \\
\text { from the enhanced PAGE09 integrated } \\
\text { assessment model }\end{array}$ & $\begin{array}{l}\text { Long-term, } \\
\text { top down }\end{array}$ & Carbon Management \\
\hline 2016 & $\begin{array}{l}\text { Jamal Othman, } \\
\text { Yaghoob Jafari. }\end{array}$ & $\begin{array}{l}\text { Identification of the key sectors that } \\
\text { produce } \mathrm{CO}_{2} \text { emissions in Malaysia: } \\
\text { application of input-output analysis }\end{array}$ & Short-term, bottom-up & Carbon Management \\
\hline 2016 & $\begin{array}{c}\text { Rajah Rasiah, } \\
\text { Al-Amin Abul Quasem, } \\
\text { Adeel Ahmed. } \\
\text { Walter Leal Filho, } \\
\text { Eduardo Calvo. }\end{array}$ & $\begin{array}{l}\text { Climate mitigation roadmap: assessing } \\
\text { low carbon scenarios for Malaysia }\end{array}$ & $\begin{array}{l}\text { Long-term, } \\
\text { top down }\end{array}$ & Journal of Cleaner Production \\
\hline 2017 & $\begin{array}{l}\text { Masoud Yahoo, } \\
\text { Jamal Othman. }\end{array}$ & $\begin{array}{l}\text { Employing a CGE model in analysing the } \\
\text { environmental and economy-wide } \\
\text { impacts of } \mathrm{CO}_{2} \text { emission abatement } \\
\text { policies in Malaysia }\end{array}$ & Short-term, bottom-up & $\begin{array}{l}\text { Science of the Total } \\
\text { Environment }\end{array}$ \\
\hline
\end{tabular}


Table A1. Cont.

\begin{tabular}{|c|c|c|c|c|}
\hline Year & Author & Name of Article & $\begin{array}{l}\text { Thematic } \\
\text { Focus }\end{array}$ & Journal \\
\hline 2017 & $\begin{array}{l}\text { Kazeem Alasinrin Babatundea, } \\
\text { Rawshan Ara Begum, } \\
\text { Fathin Faizah Said. }\end{array}$ & $\begin{array}{l}\text { Application of computable general } \\
\text { equilibrium (CGE) to climate change } \\
\text { mitigation policy: A systematic review }\end{array}$ & $\begin{array}{l}\text { Review } \\
\text { paper }\end{array}$ & $\begin{array}{l}\text { Renewable and Sustainable } \\
\text { Energy Reviews }\end{array}$ \\
\hline 2017 & $\begin{array}{c}\text { Rajah Rasiah, } \\
\text { Al-Amin Abul Quasem, } \\
\text { Nazia Mintz Habib, } \\
\text { Anwar Hossain Chowdhury, Santha } \\
\text { Chenayah Ramu, Ferdous Ahmed, } \\
\text { Walter Leal Filho. }\end{array}$ & $\begin{array}{l}\text { Assessing climate change mitigation } \\
\text { proposals for Malaysia: Implications for } \\
\text { emissions and abatement costs }\end{array}$ & $\begin{array}{l}\text { Long-term, } \\
\text { top down }\end{array}$ & Journal of Cleaner Production \\
\hline 2017 & $\begin{array}{l}\text { Danlami, } \\
\text { Abubakar Hamid, } \\
\text { Applanaidu Shri Dewi, } \\
\text { Islam Rabiul. }\end{array}$ & $\begin{array}{l}\text { Movement towards a low carbon emitted } \\
\text { environment: a test of some factors in } \\
\text { Malaysia }\end{array}$ & $\begin{array}{l}\text { Review } \\
\text { paper }\end{array}$ & $\begin{array}{l}\text { Environment, Development } \\
\text { and Sustainability }\end{array}$ \\
\hline 2018 & $\begin{array}{l}\text { Kum Yeen Wong, } \\
\text { Joon Huang Chuah, } \\
\text { Chris Hope. }\end{array}$ & $\begin{array}{l}\text { As an emerging economy, should } \\
\text { Malaysia adopt carbon taxation? }\end{array}$ & $\begin{array}{l}\text { Review } \\
\text { paper }\end{array}$ & Energy and Environment \\
\hline 2018 & $\begin{array}{l}\text { Rajah Rasiah, } \\
\text { Fatimah Kari, } \\
\text { Yuri Sadoi, } \\
\text { Nazia Mintz-Habib. }\end{array}$ & $\begin{array}{c}\text { Climate change and sustainable } \\
\text { development issues: arguments and } \\
\text { policy initiatives }\end{array}$ & $\begin{array}{l}\text { Review } \\
\text { paper }\end{array}$ & $\begin{array}{l}\text { Journal of the Asia Pacific } \\
\text { Economy }\end{array}$ \\
\hline 2019 & $\begin{array}{l}\text { Adeel Ahmed, } \\
\text { Al-Amin Abul Quasem, } \\
\text { Rajah Rasiah. }\end{array}$ & $\begin{array}{l}\text { COP negotiations and Malaysian climate } \\
\text { change roadmap: a comparative } \\
\text { assessment using a dynamic } \\
\text { environmental model }\end{array}$ & $\begin{array}{l}\text { Long-term, } \\
\text { top down }\end{array}$ & $\begin{array}{l}\text { Environmental Science and } \\
\text { Pollution Research }\end{array}$ \\
\hline 2019 & $\begin{array}{l}\text { Md. Sujahangir Kabir Sarkar, } \\
\text { Al-Amin Abul Quasem, } \\
\text { Walter Leal Filho. }\end{array}$ & $\begin{array}{l}\text { Revisiting the social cost of carbon after } \\
\text { INDC implementation in Malaysia: } 2050\end{array}$ & $\begin{array}{l}\text { Long-term, } \\
\text { top down }\end{array}$ & $\begin{array}{l}\text { Environmental Science and } \\
\text { Pollution Research }\end{array}$ \\
\hline 2020 & $\begin{array}{c}\text { Mahesh Vaka, } \\
\text { Rashmi Walvekar, } \\
\text { Abdul Khaliq Rasheed, Mohammad } \\
\text { Khalid. }\end{array}$ & $\begin{array}{l}\text { A review on Malaysia's solar energy } \\
\text { pathway towards carbon-neutral } \\
\text { Malaysia beyond Covid'19 pandemic }\end{array}$ & $\begin{array}{l}\text { Review } \\
\text { paper }\end{array}$ & Journal of Cleaner Production \\
\hline 2020 & $\begin{array}{l}\text { Hanaoka, } \\
\text { Tatsuya, } \\
\text { Masui, } \\
\text { Toshihiko. }\end{array}$ & $\begin{array}{l}\text { Exploring effective short-lived climate } \\
\text { pollutant mitigation scenarios by } \\
\text { considering synergies and trade-offs of } \\
\text { combinations of air pollutant measures } \\
\text { and low carbon measures towards the } \\
\text { level of the } 2^{\circ} \mathrm{C} \text { target in Asia }\end{array}$ & $\begin{array}{l}\text { Review } \\
\text { paper }\end{array}$ & Environmental Pollution \\
\hline
\end{tabular}

\section{References}

1. Pigou, A.C. The Economics of Welfare, 4th ed.; Macmillan and Co., Limited: London, UK, 1920; ISBN 9781351304368.

2. Tol, R.S.J. A social cost of carbon for (almost) every country. Energy Econ. 2019, 83, 555-566. [CrossRef]

3. IPCC. Global Warming of $1.5^{\circ}$ C. 2019. Available online: https://www.ipcc.ch/sr15/ (accessed on 10 November 2020).

4. Nordhaus, W. Revisiting the social cost of carbon. Dep. Econ. 2016. [CrossRef] [PubMed]

5. Stern, N. The Economics of Climate Change: The Stern Review, 1st ed.; Cambridge University Press: Cambridge, MA, USA, 2007; ISBN 978-0-521-700801.

6. IPCC. Climate Change 2014 Synthesis Report. 2014. Available online: https://www.ipcc.ch/site/assets/uploads/2018/05/SYR_ AR5_FINAL_full_wcover.pdf (accessed on 10 November 2020).

7. Nordhaus, W. A Question of Balance; Yale University Press: New Haven, CT, USA; London, UK, 2008; Volume 339, ISBN 978-0-30013748-4.

8. van der Ploeg, F.; Rezai, A. The agnostic's response to climate deniers: Price carbon! Eur. Econ. Rev. 2019, 111, 70-84. [CrossRef]

9. World Bank. State and Trends of Carbon Pricing 2020; World Bank: Washington, DC, USA, 2020.

10. World Bank; Ecofys; Economics, V. State and Trends of Carbon Pricing 2016; World Bank Group: Washington, DC, USA, 2016.

11. Eleventh Malaysia Plan. 2015. Available online: https://policy.asiapacificenergy.org/sites/default/files/11th\%20Malaysia\%20 plan.pdf (accessed on 10 November 2020).

12. Malaysia Third National Communication and Second Biennial Update Report to the UNFCCC; Putrajaya. 2018. Available online: https://unfccc.int/sites/default/files/resource/Malaysia\%20NC3\%20BUR2_final\%20high\%20res.pdf (accessed on 10 November 2020).

13. Fairbrother, M.; Johansson Sevä, I.; Kulin, J. Political trust and the relationship between climate change beliefs and support for fossil fuel taxes: Evidence from a survey of 23 European countries. Glob. Environ. Chang. 2019, 59, 102003. [CrossRef]

14. Rasiah, R.; Al-Amin, A.Q.; Chowdhurry, A.H.; Ahmed, F.; Zhang, C. Chowdhury Climate change mitigation projections for ASEAN Climate change mitigation projections for ASEAN. J. Asia Pac. Econ. 2018. [CrossRef] 
15. Joshi, D. A Proposal for Carbon Price-and-Rebate (CPR) in Malaysia. Penang Inst. Issues 2019, 1-23. Available online: https:/ / penanginstitute.org/publications/issues/a-proposal-for-carbon-price-and-rebate-cpr-in-malaysia/\#: :text=Acarbonpricingschemecommencing, revenuesoverthenextdecade (accessed on 29 December 2020).

16. Zhang, K.; Wang, Q.; Liang, Q.M.; Chen, H. A bibliometric analysis of research on carbon tax from 1989 to 2014. Renew. Sustain. Energy Rev. 2016, 58, 297-310. [CrossRef]

17. Pullin, A.S.; Stewart, G.B. Guidelines for systematic review in conservation and environmental management. Conserv. Biol. 2006, 20, 1647-1656. [CrossRef]

18. Fatorić, S.; Seekamp, E. Are cultural heritage and resources threatened by climate change? A systematic literature review. Clim. Chang. 2017, 142, 227-254. [CrossRef]

19. Ayodele, B.V.; Mustapa, S.I. Life cycle cost assessment of electric vehicles: A review and bibliometric analysis. Sustainablity 2020, 12, 2387. [CrossRef]

20. Manne, A.; Richels, R. Buying greenhouse insurance. Energy Policy 1991, 19, 543-552. [CrossRef]

21. Nordhaus, W. To Slow or Not to Slow: The Economics of the Greenhouse Effect. Econ. J. 1991, 101, 920-937. [CrossRef]

22. Titus, J.G. The Cost of Climate Change to The United States; U.S. Environmental Protection Agency: Washington, DC, USA, 1992.

23. Fankhauser, S. The economic costs of global warming damage: A survey. Glob. Environ. Chang. 1994, 4, 301-309. [CrossRef]

24. Cline, W.R. The Economics of Global Warming; Institute for International Economics: Washington, DC, USA, 1992; ISBN 0-881321508.

25. Kellett, C.M.; Weller, S.R.; Faulwasser, T.; Grüne, L.; Semmler, W. Annual Reviews in Control Feedback, dynamics, and optimal control in climate economics. Annu. Rev. Control 2019, 47, 7-20. [CrossRef]

26. Tian, L.; Ye, Q.; Zhen, Z. A new assessment model of social cost of carbon and its situation analysis in China. J. Clean. Prod. 2019, 211, 1434-1443. [CrossRef]

27. Houghton, J.T.; Jenkins, G.J.; Ephraums, J.J. Climate Change the IPCC Scientific Assessment; Cambridge University Press: Cambridge, MA, USA, 1990; Volume 1.

28. Nordhaus, W.; Yang, Z. A regional dynamic general-equilibrium model of alternative climate-change strategies. Am. Econ. Rev. 1996, 86, 741-765.

29. Nordhaus, W.; Boyer, J. Warming the World; The MIT Press: London, UK, 2000; ISBN 0262140713.

30. Hope, C.; Anderson, J.; Wenman, P. Policy analysis of the greenhouse effect an application of the PAGE model. Energy Policy 1993, 21, 327-338. [CrossRef]

31. Hope, C. The PAGE09 Integrated Assessment Model: A Technical Description. 2011. Available online: https://www.jbs.cam.ac. uk/wp-content/uploads/2020/08/wp1104.pdf (accessed on 29 December 2020).

32. Asian Development Bank. The Economics of Climate Change in Southeast Asia: A Regional Review; Asian Development Bank: Manila, Philippines, 2009.

33. Stern, N. STERN REVIEW: The Economics of Climate Change Executive Summary; Cambridge University Press: Cambridge, UK, 2007.

34. Tol, R.S.J. On the optimal control of carbon dioxide emissions: An application of FUND. Environ. Model. Assess. 1997, 2, 151-163. [CrossRef]

35. Interagency Working Group on Social Cost of Carbon. Technical Support Document: Technical Update of the Social Cost of Carbon for Regulatory Impact Analysis-Under Executive Order 12866-July 2015 Revision. 2010. Available online: https:/ /19january2 017snapshot.epa.gov/climatechange/social-cost-carbon-technical-documentation_.html (accessed on 29 December 2020).

36. Nordhaus, W. Climate Casino: Risk, Uncertainty, and Economics for a Warming World; Yale University Press: New Haven, CT, USA; London, UK, 2013; ISBN 978-0-300-21264-8.

37. Best, R.; Zhang, Q.Y. What explains carbon-pricing variation between countries? Energy Policy 2020, 143, 111541. [CrossRef]

38. Gary, W.Y.; Rodel, D.L. Perspectives on climate change and sustainability; Parry, M.L., Canziani, O.F., Palutikof, J.P., Linden, P.J., van der Hanson, C.E., Eds.; Cambridge University Press: Cambridge, MA, USA, 2006.

39. IPCC. Climate Change 1995: Impacts, Adaptations, and Mitigation of Climate Change: Scientific-Technical Analyses; Watson, R.T., Zinyowera, M.C., Moss, R.H., Eds.; Cambridge University Press: New York, NY, USA, 1996; ISBN 052156431X.

40. IPCC. Fourth Assesment Report-Workgroup II: Impacts, Adaptation and Vulnerability; Cambridge University Press: Cambrdige, UK, 2007.

41. Stern, N. The Economics of Climate Change; Cambridge University Press: Cambridge, UK, 2008.

42. Pindyck, R.S. The social cost of carbon revisited 次. J. Environ. Econ. Manag. 2019, 94, 140-160. [CrossRef]

43. Barros, V.R.; Field, C.B.; Dokken, D.J.; Mastrandrea, M.D.; Mach, K.J.; Bilir, T.E.; Chatterjee, M.; Ebi, K.L.; Estrada, Y.O.; Genova, R.C.; et al. IPCC, 2014: Climate Change 2014: Impacts, Adaptation, and Vulnerability. Part B: Regional Aspects. Contribution of Working Group II to the Fifth Assessment Report of the Intergovernmental Panel on Climate Change; Cambridge University Press: Cambridge, MA, USA, 2014.

44. Mendelsohn, R.; Morrison, W.; Schlesinger, M.E.; Andronova, N.G. Country-specific market impacts of climate change. Clim. Chang. 2000, 45, 553-569. [CrossRef]

45. Rasiah, R.; Ahmed, A.; Al-Amin, A.Q.; Chenayah, S. Climate change mitigation: Comparative assessment of Malaysian and ASEAN scenarios. Environ. Sci. Pollut. Res. 2017, 24, 2632-2642. [CrossRef] [PubMed]

46. Nordhaus, W. Integrated economic and climate modeling. In Handbook of Computable General Equilibrium Modeling; Dixon, P.B., Jorgenson, D., Eds.; Elsevier: Oxford, UK, 2013; Chapter 16; pp. 1069-1131, ISBN 978-0-444-59556-0. 
47. Plambeck, E.L.; Hope, C. PAGE95 an updated valuation of the impacts of global warming. Energy Policy 1996, $24,783-793$. [CrossRef]

48. Alcamo, J. Modeling the Global Society -Biosphere-Climate System: Part 1: Model Description and Testing. In IMAGE 2.0, Integrated Modeling of Global Climate Change; Kluwer Academic Publishers: Bilthoven, The Netherlands, 1994; pp. 1-35.

49. Doelman, J.C.; Stehfest, E.; Tabeau, A.; van Meijl, H.; Lassaletta, L.; Gernaat, D.E.H.J.; Neumann-Hermans, K.; Harmsen, M.; Daioglou, V.; Biemans, H.; et al. Exploring SSP land-use dynamics using the IMAGE model: Regional and gridded scenarios of land-use change and land-based climate change mitigation. Glob. Environ. Chang. 2018, 48, 119-135. [CrossRef]

50. Robinson, S. Macroeconomics, financial variables, and computable general equilibrium models. World Dev. 1991, 19, 1509-1525. [CrossRef]

51. Watkiss, P.; Anthoff, D.; Downing, T.E.; Hepburn, C.J.; Hope, C.; Hunt, A.; Tol, R.S.J. The Social Costs of Carbon ReviewMethodological Approaches for Using SCC Estimates in Policy Assessment; Department for Environment, Food and Rural Affairs: Oxford, UK, 2005.

52. Chang, N.; Han, C. Cost-push impact of taxing carbon in China: A price transmission perspective. J. Clean. Prod. 2020, 248, 119194. [CrossRef]

53. Ojha, V.P.; Pohit, S.; Ghosh, J. Recycling carbon tax for inclusive green growth: A CGE analysis of India. Energy Policy 2020, 144, 111708. [CrossRef]

54. Wong, K.Y.; Chuah, J.H.; Hope, C. The impact of time horizon on integrated climate assessment models. Clean Technol. Environ. Policy 2015, 17, 2361-2374. [CrossRef]

55. Khastar, M.; Aslani, A.; Nejati, M.; Bekhrad, K.; Naaranoja, M. Evaluation of the carbon tax effects on the structure of Finnish industries: A computable general equilibrium analysis. Sustain. Energy Technol. Assess. 2020, 37, 100611. [CrossRef]

56. Ministry of Natural Resources and Environment Malaysia. National Policy on Climate Change; Ministry of Natural Resources and Environment Malaysia: Putrajaya, Malaysia, 2009; p. 32.

57. Al-Amin, A.Q.; Filho, W.L. An overview of prospects and challenges in the field of climate change in Malaysia. Int. J. Glob. Warm. 2011, 3, 390. [CrossRef]

58. EPU, (Economic Planning Unit). Economics of Climate Change for Malaysia (ECCM) Inception Report. 2011. Available online: https://www.undp.org/content/dam/malaysia/docs/EnE/74235_ECCM/Economics\%20of\%20Clmate\%20Change\% 20for\%20Malaysia_Inception\%20report\%20January\%2025_26\%202012.pdf (accessed on 30 December 2020).

59. Othman, J.; Jafari, Y. Identification of the key sectors that produce $\mathrm{CO}_{2}$ emissions in Malaysia: Application of input-Output analysis. Carbon Manag. 2016, 3004. [CrossRef]

60. Othman, J.; Yahoo, M. Reducing $\mathrm{CO}_{2}$ Emissions in Malaysia: Do Carbon Taxes Work? Kuala Teren. 2014, 9, 17-19. [CrossRef]

61. Solaymani, S.; Kari, F. Environmental and economic effects of high petroleum prices on transport sector. Energy 2013, 60, 435-441. [CrossRef]

62. Wong, K.Y.; Chuah, J.H.; Hope, C. Carbon taxation in Malaysia: Insights from the enhanced PAGE09 integrated assessment model. Carbon Manag. 2016, 7, 301-312. [CrossRef]

63. Al-Amin, A.Q.; Rasiah, R.; Chenayah, S. Prioritizing climate change mitigation: An assessment using Malaysia to reduce carbon emissions in future. Environ. Sci. Policy 2015, 50, 24-33. [CrossRef]

64. University of Malaya Malaysian Carbon Tax Could Pave Way to Renewable Energy Future. 2016. Available online: https: / / phys.org/news / 2016-04-malaysian-carbon-tax-pave-renewable.html (accessed on 30 December 2020).

65. The Government of Malaysia. Intended Nationally Determined Contribution of the Government of Malaysia; Ministry of Natural Resource \& Environment: Putrajaya, Malaysia, 2015.

66. Kamaruddin, S.B. Carbon Tax Suitable for Malaysia. 2014. Available online: http://www.ukm.my/news/archive/tahun-2014 / february-2014/carbon-tax-suitable-for-malaysia / (accessed on 30 December 2020).

67. Govt Should Introduce Logging, Carbon Taxes. 2018. Available online: https://www.nst.com.my/news/nation/2018/10/4243 76/govt-should-introduce-logging-carbon-taxes (accessed on 30 December 2020).

68. EPU (Economic Planning Unit) Preparation for Twelfth Malaysia Plan. Available online: rmke12.mea.gov.my/\%0D (accessed on 5 December 2020).

69. Oil \& Gas, Energy \& Environment Team. Malaysia's Future Energy Landscape 2018; Economic Planning Unit: Putrajaya, Malaysia, 2018.

70. Singapore 1st NDC. Singapore Government, 2020. Available online: https://www4.unfccc.int/sites/ndcstaging/Pages/Party. aspx?party=SGP\&prototype=1 (accessed on 30 December 2020).

71. Government of Vietnam. Intended Nationally Determined Contribution of Viet Nam, Submission to UNFCCC. 2016. Available online: http:/ / www4.unfccc.int/submissions/INDC/PublishedDocuments/VietNam/1/VIETNAM'SINDC.pdf (accessed on 30 December 2020).

72. Ramstein, C.; Dominioni, G.; Ettehad, S.; Lam, L.; Quant, M.; Zhang, J.; Mark, L.; Nierop, S.; Berg, T.; Leuschner, P.; et al. ICAP State and Trends of Carbon Pricing 2019; World Bank Group: Washington, DC, USA, 2019; ISBN 9781464814358.

73. Alasinrin, B.K.; Begum, R.A.; Said, F.F. Application of computable general equilibrium (CGE) to climate change mitigation policy: A systematic review Application of computable general equilibrium (CGE) to climate change mitigation policy: A systematic review. Renew. Sustain. Energy Rev. 2017, 78, 61-71. [CrossRef] 
74. Ling, K.; Othman, J. The influence of economic, technical, and social aspects on energy- associated $\mathrm{CO}_{2}$ emissions in Malaysia: An extended Kaya identity approach. Energy 2020, 181, 468-493. [CrossRef]

75. Lois, J. The Sustainable Development Goals Report; United Nations Publications: New York, NY, USA, 2017.

76. Bekhet, H.A.; Othman, N.S. The role of renewable energy to validate dynamic interaction between $\mathrm{CO}_{2}$ emissions and GDP toward sustainable development in Malaysia. Energy Econ. 2018, 72, 47-61. [CrossRef]

77. Al-Amin, A.Q.; Azam, M.N.; Kari, F.; Filho, W.L. Assessing the scenario concerning environmental sustainability in Malaysia. Sci. Res. Essays 2011, 6. [CrossRef]

78. Azmi, M.; Tokai, A. System dynamic modeling of $\mathrm{CO}_{2}$ emissions and pollutants from passenger cars in Malaysia, 2040. Environ. Syst. Decis. 2016, 36, 335-350. [CrossRef]

79. Al-amin, A.Q.; Filho, W.L.; Kabir, M.A.; Azam, M.N. Climate Change Impacts: Prioritizing Mechanism and Needs for Future Climate change impacts. Int. J. Phys. Sci. 2011, 6, 1742-1748. [CrossRef]

80. Ahmed, F.; Al-Amin, A.Q.; Mohamad, Z.F.; Chenayah, S. Agriculture and food security challenge of climate change: A dynamic analysis for policy selection. Sci. Agric. 2015, 73. [CrossRef]

81. Masud, M.M.; Al-Amin, A.Q.; Junsheng, H.; Ahmed, F.; Yahaya, S.R.; Akhtar, R.; Banna, H. Climate change issue and theory of planned behaviour: Relationship by empirical evidence. J. Clean. Prod. 2016, 113. [CrossRef]

82. Bekhet, H.A.; Othman, N.S. Impact of urbanization growth on Malaysia $\mathrm{CO}_{2}$ emissions: Evidence from the dynamic relationship. J. Clean. Prod. 2017, 154, 374-388. [CrossRef]

83. Nurdianto, D.A.; Resosudarmo, B.R. The Economy-Wide Impact of a Uniform Carbon Tax in ASEAN. 2010. Available online: https:/ / www.utas.edu.au/_data/assets/pdf_file/0003/407460/20130830_Resosudarmo_2.pdf (accessed on 30 December 2020).

84. Rasiah, R.; Ahmed, A.; Al-Amin, A.Q.; Chenayah, S. Climate mitigation roadmap: Assessing low carbon scenarios for Malaysia. J. Clean. Prod. 2016, 133. [CrossRef]

85. Al-Amin, A.Q.; Siwar, C.; Hamid, A. Computable general equilibrium techniques for carbon tax modeling. Am. J. Environ. Sci. 2009, 5, 330-340. [CrossRef]

86. MNRE. Malaysia Second National Communication to the UNFCCC; Ministry of Natural Resources and Environment Malaysia: Putrajaya, Malaysia, 2011.

87. Oh, T.H.; Chua, S.C. Energy efficiency and carbon trading potential in Malaysia. Renew. Sustain. Energy Rev. 2010, 14, 2095-2103. [CrossRef]

88. UNFCCC Paris Agreement. Conference. Parties Its Twenty-First Session. 2015. Available online: http://unfccc.int/resource/ docs/2015/cop21/eng/109r01.pdf (accessed on 30 December 2020).

89. Allen, M.; Babiker, M.; Chen, Y.; de Coninck, H.; Connors, S.; van Diemen, R.; Dube, O.P.; Ebi, K.; Engelbrecht, F.; Ferrat, M.; et al. Summary for Policymakers. In Global Warming of $1.5^{\circ} \mathrm{C}$. An IPCC Special Report on the Impacts of Global Warming of $1.5^{\circ} \mathrm{C}$ above Pre-Industrial Levels and Related Global Greenhouse Gas Emission Pathways, in the Context of Strengthening the Global Response to the Threat of Climate Change, Sustainable Development, and Efforts to Eradicate Poverty; World Meteorological Organization: Geneva, Switzerland, 2018.

90. Nordhaus, W.; Paul, S. DICE 2013R: Introduction and User's Manual. 2013. (yale.edu). Available online: https://www.DICE_ Manual_100413r1.pdf (accessed on 30 December 2020).

91. Yahoo, M.; Othman, J. Carbon and energy taxation for CO2 mitigation: A CGE model of the Malaysia. Environ. Dev. Sustain. 2015, 19, 239-262. [CrossRef]

92. Yahoo, M.; Othman, J. Employing a CGE model in analysing the environmental and economy-wide impacts of $\mathrm{CO}_{2}$ emission abatement policies in Malaysia. Sci. Total Environ. 2017, 584-585, 234-243. [CrossRef]

93. Solaymani, S.; Kardooni, R.; Yusoff, S.B.; Kari, F. The impacts of climate change policies on the transportation sector. Energy 2015, 81, 719-728. [CrossRef]

94. Al-Amin, A.Q.; Jaafar, A.H.; Siwar, C. Climate change mitigation and policy concern for prioritization. Int. J. Clim. Chang. Strategy Manag. 2010, 1, 133-145. [CrossRef]

95. Abdul Hamid, J.; Al-Amin, A.Q.; Siwar, C. A CGE Analysis of the Economic Impact of Output-Specific Carbon Tax on the Malaysian Economy. Int. J. Environ. Sci. 2010, 1, 151-161.

96. Wong, K.Y.; Chuah, J.H.; Hope, C. As an Emerging Economy, Should Malaysia Adopt Carbon Taxation. Energy Environ. 2018, 30. [CrossRef]

97. Al-Amin, A.Q.; Rasiah, R.; Habib, N.M. Greenhouse Gas Reduction Options: Towards a Climate Control Roadmap for Malaysia. Sci. Technol. Trends. 2016, 7, 65-78.

98. Rasiah, R.; Al-Amin, A.Q.; Habib, N.M.; Chowdhury, A.H.; Ramu, S.C.; Ahmed, F.; Leal Filho, W. Assessing climate change mitigation proposals for Malaysia: Implications for emissions and abatement costs. J. Clean. Prod. 2017, 167, 163-173. [CrossRef]

99. Rasiah, R.; Kari, F.; Sadoi, Y.; Mintz-Habib, N. Climate change and sustainable development issues: Arguments and policy initiatives. J. Asia Pac. Econ. 2018, 7860. [CrossRef]

100. Ahmed, A.; Al-Amin, A.Q.; Rasiah, R. COP negotiations and Malaysian climate change roadmap: A comparative assessment using a dynamic environmental model. Environ. Sci. Pollut. Res. 2019. [CrossRef]

101. Sarkar, M.S.K.; Al-Amin, A.Q.; Leal Filho, W. Revisiting the social cost of carbon after INDC implementation in Malaysia: 2050. Environ. Sci. Pollut. Res. 2019. [CrossRef] 
102. IPCC. 2006 IPCC Guidelines for National Greenhouse Gas Inventories; Eggleston, S., Buendia, L., Miwa, K., Ngara, T., Tanabe, K., Eds.; Institute for Global Environmental Strategies (IGES): Hayama, Japan, 2006; ISBN 4-88788-032-4.

103. Rozainah, M.Z.; Nazri, M.N.; Sofawi, A.B.; Hemati, Z.; Juliana, W.A. Estimation of carbon pool in soil, above and below ground vegetation at different types of mangrove forests in Peninsular Malaysia. Mar. Pollut. Bull. 2018, 137, 237-245. [CrossRef]

104. NRE. Malaysia Biennial Update Report to UNFCCC; Ministry of Natural Resource \& Environment: Kuala Lumpur, Malaysia, 2015. Available online: https://unfccc.int/sites/default/files/resource/MALBUR1.pdf (accessed on 30 December 2020).

105. Rogelj, J.; Den Elzen, M.; Höhne, N.; Fransen, T.; Fekete, H.; Winkler, H.; Schaeffer, R.; Sha, F.; Riahi, K.; Meinshausen, M. Paris Agreement climate proposals need a boost to keep warming well below $2{ }^{\circ} \mathrm{C}$. Nature 2016, 534, 631-639. [CrossRef]

106. Al-Amin, A.Q.; Masud, M.M.; Kabir Sarkar, M.S.; Filho, W.L.; Doberstein, B. Analysing the socioeconomic and motivational factors affecting the willingness to pay for climate change adaptation in Malaysia. Int. J. Disaster Risk Reduct. 2020, 50, 101708. [CrossRef]

107. IPCC. Third Assesment Report-Workgroup II: Impacts, Adaptation and Vulnerability; Cambridge University Press: Cambridge, UK, 2001. 